\title{
MEASURING THE IMPACT OF FACTORS ON THE IMPLEMENTATION OF FINANCIAL STATEMENTS UNDER THE NEW ACCOUTING REGIME AT THE PUBLIC SERVICE AND ADMINISTRATION UNITS IN VIETNAM
}

\author{
TRAN THI YEN ${ }^{1}$, LE THI BAO NHU ${ }^{2}$, NGUYEN THI PHUONG THAO ${ }^{3}$ \\ ${ }^{1}$ Lecturer of Faculty of Economics and Accounting, Quy Nhon University \\ ${ }^{2}$ Lecturer of Faculty of Finance, Accounting and Banking, University of Phan Thiet. \\ ${ }^{3}$ Lecturer of Faculty of Economics, Tay Nguyen University. \\ tranyen@qnu.edu.vn,lebaonhu@gmail.com,phuongthaoktoan@gmail.com
}

\begin{abstract}
This study examines the impact of subjective and objective factors affecting the implementation of financial statements under the new regulations of public service and administration units in Vietnam. The research model and hypothesis has been tested by SmartPLS3 software with 213 survey samples from accountants and managers working in public units in Vietnam. Research results show that: (1) The capacity of accountants at the units has a positive impact on the implementation of financial statements according to the new accounting regime; (2) The content of the new accounting regime and inspection activities of functional agencies have a positive impact on the implementation of financial statements according to the new accounting regime. These results provide some implications for the theory and implications of governance for public entities in Vietnam in implementing financial statements to improve the quality of information on financial statements, serving the needs of increasing accountability and decision-making of units.
\end{abstract}

Keywords. Circular 107/2017/TT-BTC, financial statements, public sector.

\section{INTRODUCTION}

The public sector around the world has undergone some changes recently in the direction of bringing public sector activities closer to private businesses [1]. These changes have been known as the New Public Management movement (NPM) [2], get started in the late 1980s. NPM is characterized by a movement towards a new culture that emphasizes people's satisfaction and their participation in public management, establishing measures to measure results and accountability, open to public sector organizations to compete, and improve the assessment and decentralization processes in public service management [3]. One of the most important aspects of NPM is the trend of financial information system reform. Accrual accounting reform introduced by NPM, provide accurate information about the solvency of the government, the cost of public services and the results of operations $[4,5]$. Thus, the introduction of the accrual basis in government accounting systems is one of the initial and perhaps determining steps in the reform of public financial management [6]. During the past 30 years, there has been a wave of reforms in government and public sector accounting systems, focusing mainly on implementing accrualbased accounting systems and seeking convergence with the business accounting model [7]. International organizations, such as the Organization for Economic Co-operation and Development (OECD), the World Bank, and the International Monetary Fund (IMF), are pushing for convergence towards accrual accounting and international public sector accounting standards (IPSAS) to create high-quality comparable data, to facilitate auditing and to fight corruption, by improving accountability $[7,8]$. The adoption of International Public Sector Accounting Standards (IPSAS) is referred to in the literature as a crucial starting point for public-sector accounting changes [9].

For Vietnam, in recent years with an open-door policy, increasing bilateral relations and multilateral relations, Vietnam has increasingly affirmed its position in the international market [10]. In the 
multilateral commitments that Vietnam has signed, it must comply with the agreed roadmap with a commitment to transparency in accounting information, especially transparency of public sector accounting information. This has created a need to demand standardized, comparable, and internationally recognized information [11]. However, the reality of the public sector accounting regime in Vietnam still has many differences compared to public sector accounting in the world. Currently, Vietnam has no accounting standards applied to the public sector [12]. There are many different accounting regimes applied to different types of public units, for example, the public service and administration accounting regime, the commune accounting system, the social insurance accounting regime, etc [13]. With the changes in the state administrative reform and the shift of the financial mechanism to autonomy, the requirement of information transparency to make the administrative and administrative accounting regime comply with Decision No. 19/2006/QD-BTC with Circular 185/2010/TT-BTC is no longer appropriate. Therefore, the Ministry of Finance on the basis of the spiritual approach of the International Public Accounting Standards (IPSAS) has drafted and issued Circular 107/2017/TT-BTC guiding the administrative accounting system, replacing the old accounting regime. The introduction of Circular $107 / 2017 /$ TT-BTC has created a revolution that plays an important role in minimizing the difference between the public sector accounting regime in Vietnam and the public sector accounting of countries in the world are using IPSAS [14].

Financial reporting is one of the core functions of accounting in all target search organizations, including public sector organizations [15]. The financial statements give stakeholders the accounting report on financial results, financial situation, and the source and use of cash held in a financial period determined or end of the period [16]. Public sector financial reporting is an extremely important source of information for the synthesis and control of the management and use of the state budget, which is the basis for assessing socio-economic efficiency for types of public services have been implemented and provided [11]. IPSASB [17] stressed that the main purpose of the financial statements of public sector organizations is to provide useful information to users for purposes of accountability and decision-making purposes. Accordingly, the financial statements need to provide the following information of the unit: Property, payables, net asset or equity, revenue, cost, and Cash flows [18]. Circular 107/2017/TT-BTC takes effect from January 1, 2018, guiding the implementation of financial reports of public service and administration units in Vietnam on the basis of approaching IPSAS. Thanh and Yen [19] conducted a study using qualitative and quantitative methods to determine the factors affecting the application of new accounting regimes in public service and administration units in Binh Dinh province. Accordingly, Thanh and Yen [19] has discovered five influential factors including accounting staff capacity, managers' awareness, legal environment, accounting regime and inspection activities. Our research continues to identify and measure the impact of these factors on the implementation of financial statements under Circular 107 by quantitative methods with the support of SmartPLS3 software. This paper inherits the factors that Thanh and Yen [19] have given in their research, however, we provide more preliminary evidence of fundamental theory and other empirical studies that also demonstrate the appearance of these factors. In addition, we consider the influence of factors in the relationship when the public service and administration units in Vietnam are in the process of implementing financial statements as required by Circular 107. This article tries to contribute more theoretically, indicating the internal factors (according to contingency theory) and external factors (institutional theory) expected to affect work efficiency of the organization, namely the implementation of financial statements. In addition, the research results will be a useful reference source for public agencies to identify the causes affecting the work of making financial statements at the units to have better ways to handle and improve.

The paper is structured as follows: The first section presents the research context, the research gap and the importance of research; The author then presents an overview of the literature including background theory, hypotheses and research models; Then, the author presents research methods, including the presentation of sampling, how to collect data, measurement of scales and methods of data analysis. In the final section, the author presents the research results, gives implications and points out the limitations of the study. 


\section{LITERATURE REVIEW}

\subsection{Background theory}

In the public sector, an institutional theory has been used to explain how organizations respond to the pressures of their institutional environment in order to adapt $[20,21]$. Therefore, institutional theory as a guide for determining a range of external factors [22] can put pressure on or cause the internal process of the public unit changes to achieve external legitimacy [23]. Specifically, when Vietnam issued Circular 107 guiding the accounting regime applicable to public service and administration units in Vietnam, many units were reluctant to change but this is a legal regulation so they must comply. When applying Circular 107 , at the end of the fiscal year of 2018, each unit must set up financial statements according to new regulations. Accordingly, the implementation of financial statements according to the new regulations is influenced by external factors such as the legal environment, the content of the accounting regime and inspection activities of state agencies.

In addition, contingency theory was developed to be applied in the public sector by Luder [24] to explain public sector accounting and management reforms, especially the introduction of accounting systems and new report [25]. Contingency theory means that one thing is dependent on other things, and for the organizations to be effective, there must exist a "goodness of fit" between their structure and the conditions in their external environment [26]. Regarding accounting and financial reporting systems, the contingency theory is based on the premise that there is no universally appropriate accounting system which applies equally to all organizations in all circumstances [27]. The design of a new accounting system will depend on the organization's capacity to recognize and adapt to changes as a function of external and internal factors [24]. The basic nature of the contingency theory model is that the effectiveness of the organization depends on the appropriate characteristics of the organization [28]. Accordingly, compliance with the new accounting regime under Circular 107 when implementing financial statements accurately depends on the situation of the organization [29]. This study accepts the concept of contingency theory, showing that the implementation of financial statements according to the new regulations must be consistent with its contextual factors. Applying the contingency theory in this study is to explain the internal factors such as the capacity of accountants and managers' awareness has an impact on the financial statements of the units.

\subsection{Research hypothesis}

\subsubsection{Accounting staff capacity and the implementation of financial statements}

Capacity is the characteristic of a person who has the skill, knowledge and ability to perform the job [30]. The capacity of human resources is one of the important factors in determining the quality of financial reporting information [31]. In order to generate useful financial information, financial statements must be prepared by qualified staff in the field of financial management and accounting systems [32]. According to Nuryanto and Afiah [33], capacity is the ability to perform work based on skills and knowledge and is supported by the work attitude required by the job. Setiyawati [34] recognizes that the capacity of internal accountants has a significant impact on the quality of financial reporting. The author argues that the capacity of the accountant is significantly related to the quality of the financial statements [35]. Therefore, the increasing capacity of a public sector accountant to participate in the financial reporting process, it will generate better reporting quality [36]. Thanh and Yen [19] has also determined that the capacity of accountants has a significant influence on the application of new accounting regime at the public service and administration units in Binh Dinh province. Therefore, we propose the following hypothesis:

Hypothesis $1\left(\mathrm{H}_{1}\right)$ : The capacity of accountants has a positive impact on the implementation of financial statements according to the new accounting regime at the public service and administration units in Vietnam. 


\subsubsection{Manager's perception and the implementation of financial statements}

Successful accounting reforms depend on support from political leaders who establish regulations by requiring greater transparency and accountability [37]. In some cases, the manager's decisions are just stereotypes, subject to the direction from the authorities. However, the leaders in the organization have a great influence on others to understand and agree with what needs to be done and how to perform effective tasks, enabling individual and organizational efforts to reach be a common goal [38]. Thus, the perception of public sector managers affects the implementation of financial statements through their needs on the use of information on financial statements in making related decisions [39, 40]. According to Thien [35], the perception of unit managers positively affects the quality of accounting information in public schools through their encouragement of accountants to improve their qualifications. Specially, Thanh and Yen [19] have identified managers' perceptions that have a positive impact on the application of new accounting regime at the public service and administration units in Binh Dinh province. Hypothesis can be drawn as follows:

Hypothesis $2\left(\mathrm{H}_{2}\right)$ : Manager's perception has a positive impact on the implementation of financial statements according to the new accounting regime at the public service and administration units in Vietnam.

\subsubsection{Regulatory environment and the implementation of financial statements}

The political environment characteristics of each country are different, which makes a difference in the legal environment because legal regulations are a tool to institutionalize management and executive views of each country [24]. Therefore, all activities in all areas of a country's society must be consistent with that legal environment, and public accounting is no exception, namely the characteristics of legal documents [31]. The regulatory environment is understood as the legal basis that accountants must base on it to perform accounting work, ensuring the operation of accounting in accordance with the provisions of law [41]. Hien [11] also said that the legal environment has an impact on Vietnam's public sector accounting reforms to provide honest and useful information to users. Public accountants in Vietnam include three large areas in accordance with three parts of state finance: Accounting of budget revenues and expenditures; Accounting of public service and administration units using state budget funding; Accounting of state financial funds [13]. Van [10] also pointed out that the legal system affects the formulation of national public accounting standards in the context of using IPSAS. Thanh and Yen [19] have identified a legal environment that has a positive impact on the application of a new accounting regime at the public service and administration units in Binh Dinh province. Thereby, we realize that the legal environment factor will have a certain impact on the implementation of financial statements at public service and administration units in Vietnam. So it can be hypothesized as follows:

Hypothesis $3\left(\mathrm{H}_{3}\right)$ : Regulatory environment has a positive impact on the implementation of financial statements according to the new accounting regime at the public service and administration units in Vietnam.

\subsubsection{Content of accounting regime and the implementation of financial statements}

Accounting regimes are regulations and guidelines on accounting in a specific field or a number of specific tasks by the state management agency in charge of accounting or organization authorized by state management agencies in charge of accounting issued [42]. Korutaro Nkundabanyanga, Tauringana [43] shows that the relationship between accounting standards, legal framework and quality of financial reporting is limited to the private sector, and it is important that such studies are extended to the public sectors. Hien [11] also considers that the content of the public sector accounting regime in Vietnam needs to be carefully considered in many aspects such as the basis of recording, the system of vouchers, accounts, books and accounting reports; It is necessary to adjust the accounting regime so that it provides useful and relevant information with international accounting practices. According to Ouda [44], Thanh and Yen [45], the implementation of accounting on an accrual basis of public sector success will help improve financial report, improving the assessment of implementation, presenting the information the 
financial situation of the better asset management and better debt management. Thanh and Yen [19] said that the accounting regime has a positive impact on the application of new accounting regime at administrative and non-business units in Binh Dinh province. That means the complexity of the accounting regime content is considered one of the barriers affecting the application of accounting regimes into practice [46]. Accordingly, the more detailed, clear and easy-to-understand accounting regime will help accountants to approach and apply it [47]. Therefore, we propose the following hypothesis:

Hypothesis $4\left(\mathrm{H}_{4}\right)$ : Content of accounting regime has a positive impact on the implementation of financial statements according to the new accounting regime at the public service and administration units in Vietnam.

\subsubsection{Inspection activities and the implementation of financial statements}

Public units use state budget funding for their activities, they must be subject to inspection, supervision and auditing from state audit agencies or competent agencies [12]. Therefore, the quality of auditing, monitoring and auditing activities affects the use of funds and reports on the use of funds, the situation of operations from these units [48]. In a study of factors affecting the quality of accounting information published in financial statements of Cheng [49], the quality of audit activities has a positive impact on the level of information disclosure and quality of information on financial statements. The quality of audit activities in previous years will positively affect the quality of information published in the current year financial statements. Agung and Winarningsih [50] also demonstrated audit activities that have a positive and significant impact on the quality of financial statements in the public sector in the regional government of Bekasi Regency, Indonesia. In addition, the monitoring agency (regional inspector) should be more effective in controlling financial statement quality of public agencies [51]. Thanh and Yen [19] have identified managers' perceptions that have a positive impact on the application of new accounting regime at the public service and administration units in Binh Dinh province. From the discussion above, we make the following hypothesis:

Hypothesis $5\left(\mathrm{H}_{5}\right)$ : Inspection activities has a positive impact on the implementation of financial statements according to the new accounting regime at the public service and administration units in Vietnam.

According to institutional theory [20] and contingency theory [24], the disclosure of financial statements for the public sector to reduce information asymmetry, protect the interests of stakeholders. Combined with the above hypotheses, the authors present the research model as follows:

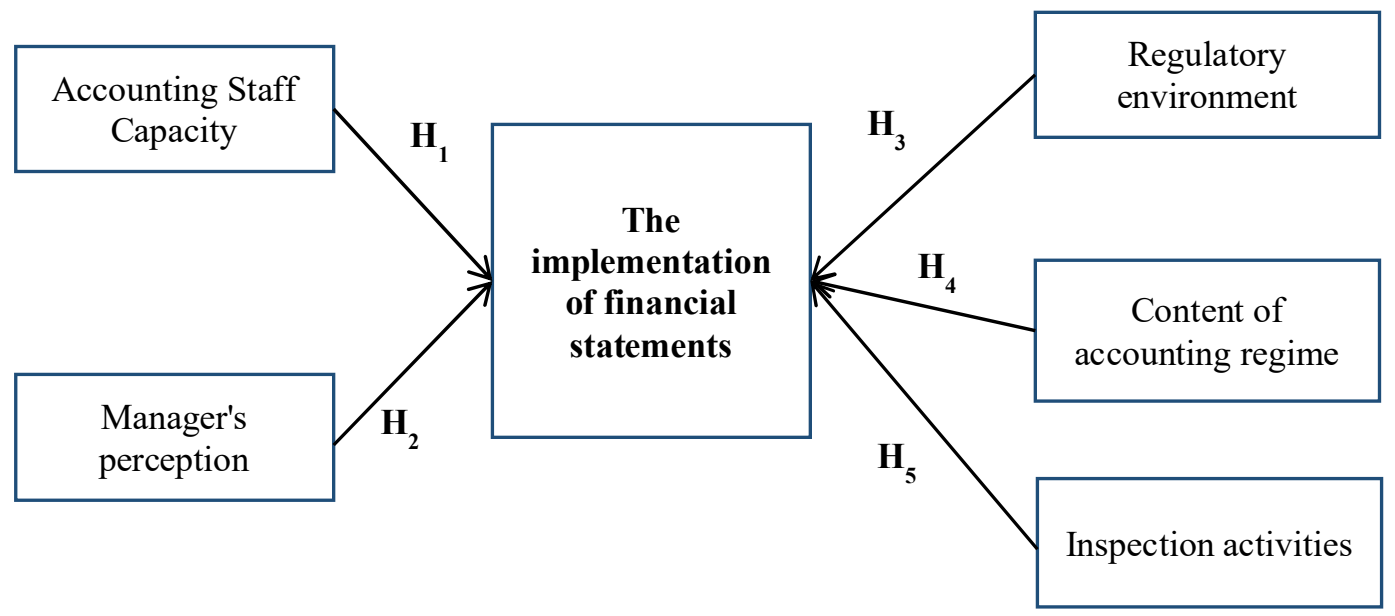

Figure 1. Research model 


\section{METHODOLOGY}

\subsection{Sampling and data collection}

Samples are selected according to self-administered survey. This sampling method is quite popular today because it means researchers can choose the objects they can access. This method has the advantage of being able to access research objects and is often used when time and economic constraints are involved. However, this method is not generalized to the crowd [52].

The unit of analysis in this paper is each Vietnam public sector entity that are applying public service and administration accounting regimes such as administrative agencies, public service about education, medical industry, cultural, sports and other social organizations in the public sector. In each entity, the authors select a representative to answer the survey questionnaire. Survey respondents are the chief accountants, accountants, managers and others related to the creation and use of information on the financial statements. The sampling criteria aim at respondents who have experience and knowledge related to the research topic, that can improve the value of research results.

Before sending official survey questionnaires, the questionnaire was tested by 10 chief accountants at administrative and public service units in Vietnam. The purpose of this step is to check the clarity of the survey questionnaire. The author sent 450 surveys via email and sent the survey directly from November 2018 to January 2019. At the end of January 2019, there were 241 responses, of which 152 responses were due to the direct questionnaire and 89 responses by email, reaching a high response rate of $53.5 \%$. After excluding incomplete response, the author has 213 valid responses.

\subsection{Measurement scales}

In this study, the authors measured the key variables in the model deriving the scale from wellestablished previous studies, which were published in high-ranking journals. The research model of this study includes an independent variable and five dependent variables with a total of 22 observed variables.

The dependent variable in the study is the implementation of financial statements according to the new accounting regime at the public service and administration units in Vietnam. Hien [11] said that the financial statements in Vietnam applied to public service and administration in particular and the public sector, in general, should include 4 types of reports to ensure compliance with international practices. Finance [53] on the basis of IPSAS approach has also issued a new accounting regime stipulating that public service and administration units must set up four types of financial statements, including Financial situation report, performance report, cash flow statements and notes to financial statements. Thus, the dependent variable is measured using the scale according to Finance [53] and IPSASB [18]. The public service and administration units need to prepare four types of financial statements. And this scale has four items with five-point Likert-type scale instrument.

Independent variables in the study include accounting staff capacity, managers' awareness, legal environment, new accounting regime and inspection activities. These independent variables are all firstorder scales. The scale for accounting staff capacity is adapted from Setiyawati [34] and Indriasih and Koeswayo [54]. This scale has four item with five-point Likert-type scale instrument. Items related to knowledge, skills, attitudes and experience. Manager's perception is measured following Yen and Thuy [48] with a three-item scale shows the manager's interest in accounting activities at the unit. Regulatory environment use is measured following Van [10]. A four-item scale was used to measure regulatory environment with five-point Likert-type scale instrument. This scale is also mentioned by Grossi [55] and Bergmann and Bietenhader [56] in their research. The scale of content of accounting regime was adjusted from Hien [11]. This scale has five items with five-point Likert-type scale instrument. Items related to an accrual accounting basis, instructions on documents, accounts, books and accounting reports. Inspection activities are measured following Thanh and Yen [19], with three-item scale and five-point Likert-type scale instrument. All of the observed variables are included in the survey with the Likert 5 scale 
showing the level of respondents' agreement with the statements, specifically: (1) Strongly disagree; (2) Do not agree; (3) Neutral; (4) Agree and (5) Strongly agree.

\section{RESEARCH RESULTS}

\subsection{Sample description statistics}

The statistical results describing the survey sample are presented in detail in Table 1. Accordingly, among 213 respondents, there are 101 accountants (accounting for 47.4\%), chief accountants account for $40.8 \%$, management and other related positions account for $11.8 \%$. The common seniority of respondents in the unit is over 5 years (accounting for 51.6\%), which shows that respondents have a lot of experience and knowledge about research issues and can represent the organization to answer the survey questionnaire. Considering the type of unit information, the authors found that revenue public service units accounted for the highest proportion (accounting for $42.3 \%$ ), followed by non-revenue public service units $32.4 \%$, administrative offices accounted for $24.4 \%$ and other social organizations account for only $0.9 \%$. Considering information on the activities of public entities, the authors found that the education and training sector accounted for the highest proportion (accounting for 54\%), followed by the health sector $29.1 \%$ and field socio-cultural sector only accounted for $8.9 \%$.

Table 1. Demographic profile of respondents $(\mathrm{n}=213)$

\begin{tabular}{|c|c|c|c|c|c|}
\hline Demographics & Frequency & Percent & Demographics & $\begin{array}{c}\text { Frequenc } \\
\mathrm{y}\end{array}$ & Percent \\
\hline Position & & & Type of unit & & \\
\hline Chief accountant & 87 & 40.8 & Administrative offices & 52 & 24.4 \\
\hline Accountant & 101 & 47.4 & $\begin{array}{l}\text { Revenue public service } \\
\text { units }\end{array}$ & 90 & 42.3 \\
\hline Head of unit & 8 & 3.8 & $\begin{array}{l}\text { Non-revenue public service } \\
\text { units }\end{array}$ & 69 & 32.4 \\
\hline Other positions & 17 & 8.0 & Other social organizations & 2 & .9 \\
\hline $\begin{array}{l}\text { Number of years of } \\
\text { experience }\end{array}$ & & & Field of operation & & \\
\hline Less than 2 years & 8 & 3.8 & Health sector & 62 & 29.1 \\
\hline From 2 years to 5 years & 43 & 20.2 & Field of education and training & 115 & 54.0 \\
\hline From 5 years to 10 years & 110 & 51.6 & Social and cultural fields & 19 & 8.9 \\
\hline Over 10 years & 52 & 24.4 & Other areas & 17 & 8.0 \\
\hline
\end{tabular}

\subsection{Scale reliability and validity}

The author used SmartPLS3 software to test the measurement model. According to the scale assessment results shown in Table 2, the authors find that the load factor of most observed variables (ranging from 0.63 to 0.91 ) was above the minimum recommended threshold of 0.50 [57]. At the same time, all corresponding t-test values of the observed variables (ranging from 8.76 to 57.35) are also satisfactory because they are larger than 1.96 to have statistical significance. The average variance (AVE) of all potential variables in the model is acceptable because it is higher than 0.50 (ranging 
from 0.66 to 0.76 ) [58]. The composite reliability (CR) of the potential variables ranges from 0.85 to 0.91 , higher than 0.708; thereby showing the high reliability of the scales used in the model [59].

Table 2. Scale items and latent variable evaluation

\begin{tabular}{cc}
\hline Construct and items & $\begin{array}{c}\text { Outer } \\
\text { loading t-test }\end{array}$
\end{tabular}

Accounting Staff Capacity (AVE=0.66; $C R=0.88$ )

Degree in the right major in public accounting

$0.833 \quad 25.110$

Information technology use level

$0.831 \quad 22.689$

Serious attitude, studious and progressive

$0.788 \quad 18.867$

Number of years of experience as an accountant

$0.785 \quad 16.306$

Manager's perception ( $A V E=0.73 ; C R=0.89)$

Managers pay much attention to the accounting operations of the unit

$0.868 \quad 36.508$

Managers appreciate the usefulness of accounting information

$0.855 \quad 27.974$

The manager accepts the high level of investment in applying a new accounting regime

$0.844 \quad 29.757$

Content of accounting regime ( $A V E=0.67 ; C R=0.91)$

The new accounting regime recognizes economic operations on the basis of $\quad \begin{array}{lll}0.783 & 23.574\end{array}$ accrual accounting

The regulations on accounting documents are easy to understand $\quad 0.856 \quad 30.945$

Regulations on accounting accounts are clear and easy to understand $\quad 0.630 \quad 8.756$

Regulations on accounting books are specific and easy to understand $\quad 0.911 \quad 38.868$

Accounting reporting regulations are clear and easy to understand $\quad 0.886 \quad 38.952$

Inspection activities $(A V E=0.66 ; C R=0.85)$

$\begin{array}{lll}\text { Strengthen inspection activities } & 0.886 & 43.620\end{array}$

$\begin{array}{ll}\text { The closely scrutinized } & 0.846 \quad 30.095\end{array}$

$\begin{array}{lll}\text { The sanctions are stronger } & 0.689 & 12.651\end{array}$

Regulatory environment $(A V E=0.76 ; C R=0.91)$

$\begin{array}{lll}\text { Guidance of the current Accounting Law } & 0.888 \quad 30.373\end{array}$

$\begin{array}{ll}\text { Guidelines of the current Budget Law } & 0.831 \quad 23.285\end{array}$

$\begin{array}{lll}\text { Guidelines of the current accounting regime } & 0.900 & 57.345\end{array}$

The implementation of financial statements according to the new accounting regime ( $A V E=0.72 ; C R=0.91$ )

The preparation of the financial situation report

$0.851 \quad 40.113$ 
The preparation of the performance report

$0.875 \quad 47.841$

The preparation of cash flow statement

$0.859 \quad 35.828$

The preparation of financial statements notes

$0.811 \quad 20.545$

Notes: AVE: Average variance extracted; CR: Composite reliability

In the next step, the authors use a number of criteria to test the distinctive value of the main measurement variables in the research model, the results shown in Table 3.

Table 3. Construct means, standard deviations, and correlations

\begin{tabular}{lrrrrrr}
\hline \multicolumn{1}{c}{ Variables } & BCTC & \multicolumn{1}{c}{ KT } & NQL & PL & REGIME & TT \\
\hline The implementation of financial & $\mathbf{0 . 8 4 9}$ & & & & & \\
statements (BCTC) & $0.335^{* *}$ & $\mathbf{0 . 8 1 0}$ & & & & \\
Accounting Staff Capacity (KT) & 0.386 & & & & & \\
& $0.401^{* *}$ & $0.352^{* *}$ & $\mathbf{0 . 8 5 6}$ & & & \\
Manager's perception (NQL) & 0.472 & 0.429 & & & & \\
& $0.466^{* *}$ & $0.349 * *$ & $0.386^{* *}$ & $\mathbf{0 . 8 7 4}$ & & \\
Regulatory environment (PL) & 0.527 & 0.419 & 0.458 & & & \\
& $0.455^{* *}$ & $0.396^{* *}$ & $0.383 * *$ & $0.599^{* *}$ & $\mathbf{0 . 8 2 0}$ & \\
Content of accounting regime & 0.520 & 0.474 & 0.452 & 0.693 & & \\
(REGIME) & $0.592^{* *}$ & $0.169^{* *}$ & $0.356^{* *}$ & $0.414^{* *}$ & $0.354 * *$ & $\mathbf{0 . 8 1 1}$ \\
& 0.735 & 0.241 & 0.443 & 0.517 & 0.436 & \\
Inspection activities (TT) & 3.75 & 3.95 & 3.75 & 3.87 & 3.85 & 3.74 \\
& 0.87 & 0.92 & 0.99 & 0.82 & 0.89 & 0.96 \\
\hline Mean & Standard deviation & & & & & \\
\hline
\end{tabular}

Note: 1 st value $=$ Correlation between variables (off diagonal); 2 nd value (italic) $=$ HTMT ratio; Square root of AVE (bold diagonal); **: Correlation is significant at the $1 \%$ level (2-tailed t-test).

First of all, the author uses the procedure proposed by Fornell and Larcker [60]. In Table 3, the square root value of the average variance (AVE) of all latent variables is in the range of 0.81 to 0.87 and is higher than all correlation coefficients between the variables (range from 0.17 to 0.59 ). Therefore, the scales of potential variables in the research model achieve discriminant value. Besides, the discriminant value of the scale is also demonstrated when all correlation coefficients between variables (numbers below the diagonal) are smaller than the composite reliability level (CR) [61]. Specifically, the results in Table 2 and Table 3 show that the values of correlation coefficients between variables (range from 0.17 to 0.59 ) are lower than the values of the aggregate confidence level (range from 0.85 to 0.91 ). This shows that the discriminant value of the scales in the model is achieved. In addition, the correlation coefficients between the variables are smaller than the cut-off value of 0.7 , thereby showing that the correlation is acceptable for discriminating value [62]. In addition, the author used a new criterion to check the discriminant value of the scale, Heterotrait-Montrait coefficient (HTMT), a more rigorous coefficient than Fornell and Larcker [60] when assessing the discriminant value of scale [63]. Table 3 shows the HTMT coefficients ranging from 0.24 to 0.74 , lower than 0.85 [58]. This further proves that the scale in the model achieves distinctive value.

\subsection{Testing hypotheses}

Verification of hypotheses in the model is carried out by the author group using SmartPLS3 software. In order to provide evidence for the testing of proposed hypotheses, the author assessed the 
magnitude and the statistically significant level of each path in the structural model representing each assumption of assumptions. The test results are presented in detail in Figure 2, including the coefficients $\beta$, the t-values for PLS3 paths in the model, as well as the adjusted R2 coefficient of the dependent variable as the implementation of financial statements according to the new accounting regime.

Based on the research results proposed by Henseler, Hubona [64], the authors calculated the model's SRMR of 0.07 , which is less than the proposed level of 0.08 . This result shows that the research model has a relative relevance to the collected data. Moreover, the results of the data analysis showed that the adjusted R2 coefficient of the dependent variable is 0.45 , which is higher than the minimum threshold of 0.10 , proving that the proposed research model has a high degree of relevance to the collected data.

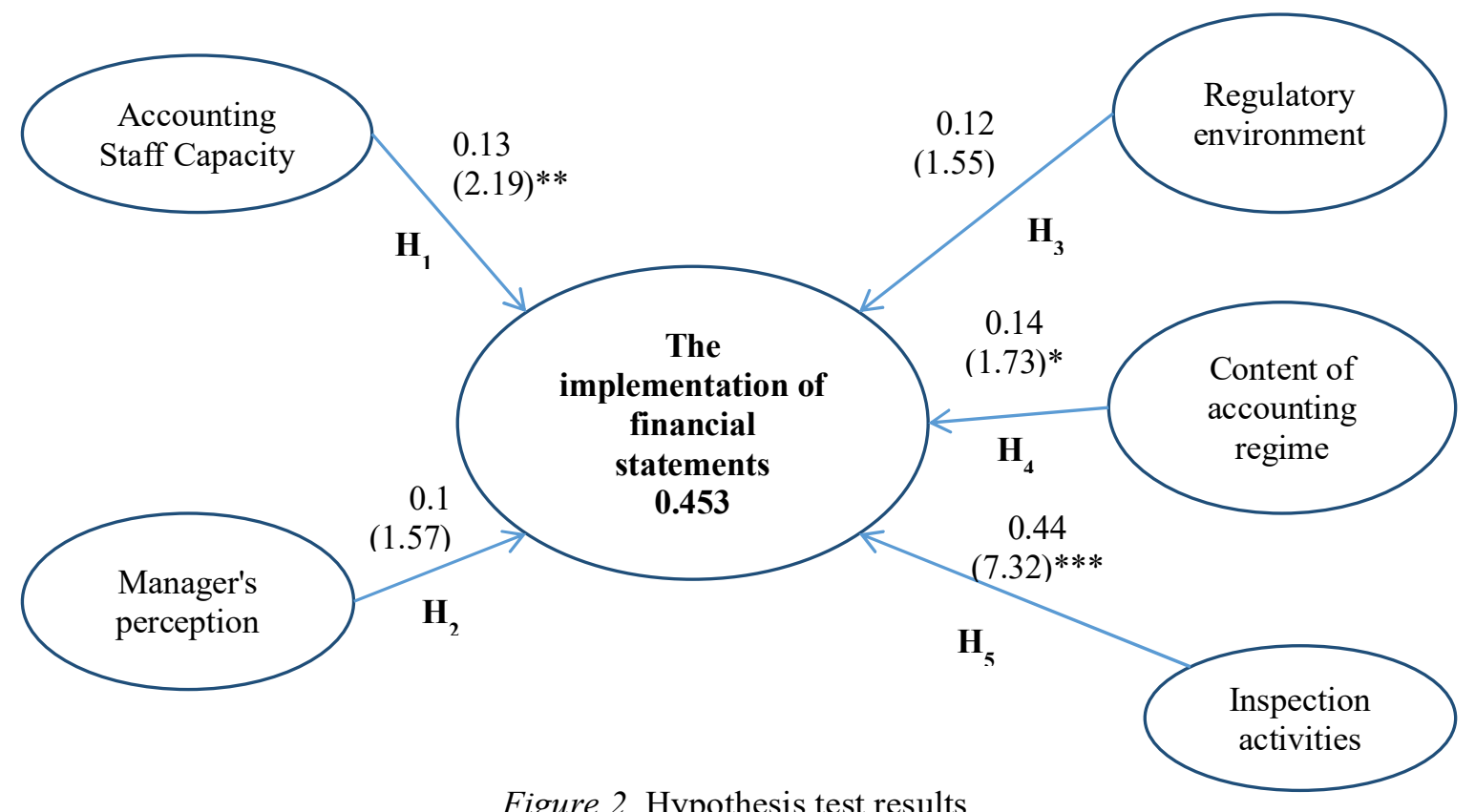

Figure 2. Hypothesis test results

Note: Number on path: In addition to parentheses () is the coefficient $\beta$; inside parentheses () is the value of t; The number in the circle is the adjusted R2 coefficient; *,**,*** corresponds to statistically significant levels of $10 \%$, $5 \%$ and $1 \%(\mathrm{t}-2$ tails test) respectively.

Hypothesis $\mathrm{H}_{1}$ proposed that the capacity of accountants has a positive impact on the implementation of financial statements according to the new accounting regime at the public service and administration units in Vietnam. This can be interpreted as accounting staff with good professional knowledge, the implementation of financial statements will be easy. The data analysis results in Figure 2 show that this hypothesis is accepted with a 5\% statistical significance ( $\mathrm{t}$ value of 2.19), it has a coefficient $\beta$ of 0.13 . Hypothesis $\mathrm{H}_{2}$ suggests that managers' perception has a positive impact on the implementation of financial statements according to the new accounting regime, means that managers are more interested in accounting, the implementation of financial statements will be easy. According to Figure 2, this hypothesis is not accepted because the t-value is 1.57 , not statistically significant at $10 \%$ with a coefficient $\beta$ of 0.1 . Hypothesis $\mathrm{H}_{3}$ suggests that regulatory environment has a positive impact on the implementation of financial statements according to the new accounting regime. Similarly, hypothesis $\mathrm{H}_{3}$ is also not accepted because the t-value is 1.55 , not statistically significant at $10 \%$ with a coefficient $\beta$ of 0.12 . Hypothesis $\mathrm{H}_{4}$ proposed that the content of the accounting regime has a positive impact on the implementation of financial statements according to the new accounting regime at the public service and administration units in Vietnam. This is understood in the sense that the content of the new accounting regime is clear and easy to understand, making the implementation of financial statements more convenient. The data analysis results in Figure 2 show that this hypothesis is accepted with a $10 \%$ 
statistical significance (t-value of 1.73 ), with a coefficient $\beta$ of 0.14 . Finally, the $\mathrm{H}_{5}$ hypothesis proposes that the test activity of the authorities has a positive effect on the implementation of financial statements according to the new accounting regime at the public service and administration units in Vietnam. Accordingly, state agencies such as inspection agencies, state audit agencies and superior units strengthen inspection and supervision activities, the implementation of financial statements will be conducted more smoothly. The analytical results show that this hypothesis is highly accepted with a statistical significance of $1 \%$ ( $t$ value is 7.32 ), with a very high coefficient $\beta$ of 0.44 .

\section{CONCLUSION AND RECOMMENDATION}

\subsection{Conclusion}

The implementation of financial statements according to the new accounting regime at the public service and administration units in Vietnam is influenced by three main factors that are statistically significant, namely accounting staff capacity, content of accounting regime and inspection activities. Accordingly, inspection activities have the strongest effect $(\beta=0.44)$, next is the content of accounting regime with $\beta$ of 0.14 and finally the accounting staff capacity $(\beta=0.13)$. However, in terms of statistical significance, the accounting staff capacity (significance level of 5\%) is significantly higher than content of accounting regime ( $10 \%$ significance level).

Compared to previous studies, especially the recent study of Thanh and Yen [19], the results of this study also show the important role of inspection and supervision. External factors play a key role in the implementation of financial statements in units, particularly the pressure of enforcement in view of institutional theory [21]. This result is also consistent with previous studies by authors like Yen and Thuy [48]; Carpenter, Cheng [21] and Cheng [49]. The internal factor of the organization has significance for the results of the financial statements implementation as accountants, in particular, their capacity. Luder [24] considers that internal factors such as human resources, it will make a difference between organizations when implementing a legal regulation together. Clearly, Circular 107 is issued by Finance [53] but how it applies depends on the context of the organization [19]. Which units have the staff with good knowledge, experience, professional skills, enthusiastic attitude, the implementation of financial statements under Circular 107 will be easy and achieve good results. In addition, the content of Circular 107 itself also affects the implementation of financial statements at the unit. Circular 107 has many differences compared to the old regulations, especially the recognition of economic operations based on accrual basis. Financial statements are the final product of accounting work, so the points of change when recording economic operations, using the right account, understanding the nature of the transaction, how to make reports are very important for the accountant. In this study, we did not find the statistical significance of the two factors as managers' perceptions and legal environment. And this is a difference from the original results of Thanh and Yen [19]. This result can be interpreted as when considering the implementation of financial statements, the internal factors such as awareness of managers - users of accounting information - are not affected but only the capacity of accountants - those who directly create accounting information - affect the implementation of financial statements according to the new accounting regime at the public service and administration units in Vietnam. The legal environment is an external factor organized, macro-nature, so the degree of its influence on the financial statements implementation is not clear.

\subsection{Recommendation}

The results of our study are important because they provide evidence of the relationship between the internal factors (accounting staff capacity), external factors (inspection activities, content of accounting regime) and the implementation of the financial statements according to the new accounting at the public service and administration units in Vietnam. In light of our findings, we believe that the inspection and supervision activities of the relevant authorities will contribute to minimizing the errors of the units when implementing financial statements. According to Thanh and Yen [19], when surveying the application of the new accounting regime at the administrative and public service units in Binh Dinh province, it is also 
found that many units are very slow in implementation because of the lack of close supervision by competent authorities. Public units are generally very passive in accessing new regulations unless they are under great pressure from stakeholders. In particular, the state audit should clearly show its role in auditing financial statements. And auditors should have sufficient, persuasive, highly independent evidence, training in accounting for fraud detection as well as close coordination with other agencies such as Procuratorate or Ministry of Public Security.

In addition, human is the most important factor, determining the success of the organization's activities. First of all, the accountants themselves need to be aware of learning and fostering professional knowledge, the level of information technology to meet the work needs well. In addition, the public service and administration units should recruit accountants with knowledge of accounting in the public sector. It is necessary to set recruitment policies to attract talents to work in important parts, avoiding relying on close relationships. The unit should have appropriate remuneration and reward policies to promote its capacity and spirit of responsibility. At the same time, the unit should focus on creating conditions, encouraging employees to participate in fostering classes, improving professional knowledge, updating new policies and regulations related to accounting.

Circular 107 was officially issued by Finance [53] for one year. However, the content of Circular 107 still has some unreasonable points, such as guidance on calculating the price of warehousing tools and tools; guidance on accounting of foreign exchange rates, etc. Therefore, the Ministry of Finance should issue a document to guide the detailed revision to make the Circular 107 more reasonable and clear. In addition, the Ministry of Finance should organize some additional training sessions to guide accounting staff at the public service and administration units to set up financial statements according to regulations. Financial statements under Circular 107 are completely different from the previous regulations on form and content. Although, the Ministry of Finance organized training courses for accountants at the units in early 2018 but the quality of these training sessions was not appreciated [19]. The training sessions should focus more on quality in order to help the units complete the financial statements in accordance with regulations, provide timely information for managers and stakeholders.

\subsection{Limitations and future research}

The value of this study is reflected in helping the public service and administration units see the cause of poor financial performance, so that solutions are found to overcome this situation. However, this study is the subject to several limitations. Firstly, we choose the sample only in a convenient way, so it can not bring high representation. Secondly, the scales used to measure variables in the model do not have many supportive studies. Finally, basing on the analysis and validation of the hypotheses in this study, it was found that the impact of factors was only $45.3 \%$. Thus, $54.7 \%$ of the other factors influence the implementation of financial statements under the new accounting regime of the public sector in Vietnam. Further research should thus take account of the above listed limitations.

\section{REFERENCES}

[1] N. Manning, The legacy of the New Public Management in developing countries. International Review of Administrative Sciences. vol. 67, no. 2 pp. 297-312, 2001.

[2] N. Hyndman, et al., Legitimating change in the public sector: the introduction of (rational?) accounting practices in the United Kingdom, Italy and Austria. Public Management Review. vol. 20, no. 9 pp. 1374-1399, 2017.

[3] C. Hood, The "New Public Management" in the 1980s: variations on a theme. Accounting, organizations and society. vol. 20, no. 2-3 pp. 93-109, 1995. 


\section{MEASURING THE IMPACT OF FACTORS ON THE IMPLEMENTATION OF FINANCIAL STATEMENTS UNDER THE NEW ACCOUTING REGIME AT THE PUBLIC SERVICE AND ADMINISTRATION UNITS IN VIETNAM}

[4] V. Pina and L. Torres, Reshaping public sector accounting: an international comparative view. Canadian Journal of Administrative Sciences/Revue Canadienne des Sciences de l'Administration. vol. 20, no. 4 pp. 334$350,2003$.

[5] J.L. Chan, Government accounting: an assessment of theory, purposes and standards. Public Money \& Management. vol. 23, no. 1 pp. 13-20, 2003.

[6] I. Brusca, M. Gómez- villegas, and V. Montesinos, Public financial management reforms: The role of IPSAS in Latin- America. Public administration and development. vol. 36, no. 1 pp. 51-64, 2016.

[7] F.M. Rossi, et al., Harmonizing public sector accounting in Europe: thinking out of the box. Public Money \& Management. vol. 36, no. 3 pp. 189-196, 2016.

[8] J.B. Da Costa Carvalho, et al., Conformity and diversity of accounting and financial reporting practices in Portuguese local government. Canadian Journal of Administrative Sciences/Revue Canadienne des Sciences de l'Administration. vol. 24, no. 1 pp. 2-14, 2007.

[9] P.S. Gomes, M.J. Fernandes, and J.B.D.C. Carvalho, The international harmonization process of public sector accounting in Portugal: the perspective of different stakeholders. International Journal of Public Administration. vol. 38, no. 4 pp. 268-281, 2015.

[10]C.T.C. Van, Study the factors affecting the development of Vietnamese public accounting standards in the context of applying international public accounting standards. 2016, University of Economics of Ho Chi Minh City. p. 138.

[11]N.T.T. Hien, Finalization of Vietnam public sector financial statements. 2015, University of Economics of Ho Chi Minh City.

[12]P.Q. Huy, Complete the accounting system of government budget revenue and expenditure in Vietnam. 2014, University of Economics Ho Chi Minh City.

[13] M.T.H. Minh. Applying International Public Sector Accounting Standards to implement government financial statements according to the general state accounting model. in Vietnam Public sector accounting in the process of global economic integration. 2014. University of Economics Ho Chi Minh City.

[14]T.T. Yen, The administrative accounting regime and the access to international public accounting standards. Review of finance. vol., no. 675 pp. 84-86, 2018.

[15]L. Oulasvirta, Public-sector accounting and the international standardization process of presenting financial statements. Administrative Culture. vol. 11, no. 2 pp. 227-238, 2010.

[16]J. Christiaens, et al., The effect of IPSAS on reforming governmental financial reporting: An international comparison. International Review of Administrative Sciences. vol. 81, no. 1 pp. 158-177, 2014.

[17] IPSASB, The conceptual framework for general purpose financial reporting by public sector entities. 2014.

[18]IPSASB, Handbook of International Public Sector Accounting Pronouncements, 2017 edition volume I. $2017 \mathrm{a}$.

[19]T.T.C. Thanh and T.T. Yen. Factors Have Affected The Application Of The New Accounting System: The Case Of The Public Service And Administration Units In Binh Dinh Province - Vietnam. in The 4th International Conference on Accounting and Finance - ICOAF 2018. 2018a. Danang City, Vietnam: Danang Publishing house. 


\section{MEASURING THE IMPACT OF FACTORS ON THE IMPLEMENTATION OF FINANCIAL STATEMENTS UNDER THE NEW ACCOUTING REGIME AT THE PUBLIC SERVICE AND ADMINISTRATION UNITS IN VIETNAM}

[20] V.L. Carpenter and E.H. Feroz, Institutional theory and accounting rule choice: an analysis of four US state governments' decisions to adopt generally accepted accounting principles. Accounting, Organizations and Society. vol. 26, no. 7-8 pp. 565-596, 2001.

[21] V.L. Carpenter, R.H. Cheng, and E.H. Feroz, Toward an empirical institutional governance theory: Analyses of the decisions by the 50 US state governments to adopt generally accepted accounting principles. vol., no. 2008.

[22]R. Akbar, R. Pilcher, and B. Perrin, Performance measurement in Indonesia: the case of local government. Pacific Accounting Review. vol. 24, no. 3 pp. 262-291, 2012.

[23]I. Lapsley, The changing public sector: from transition to transformation. European Accounting Review. vol. 10, no. 3 pp. 501-504, 2001.

[24]K. Luder, A contingency model of governmental accounting innovations in the political administrative environment. vol., no. 1992.

[25]E. Anessi- Pessina, G. Nasi, and I. Steccolini, Accounting reforms: determinants of local governments'choices. Financial Accountability \& Management. vol. 24, no. 3 pp. 321-342, 2008.

[26] A.A. Whitefield, The Adoption and Implementation of the International Public Sector Accounting Standards: The Levels of Adoption and Implementation of IPSAS by United Nations in Nairobi. Journal of Public Policy and Administration. vol. 1, no. 1 pp. 49-57, 2016.

[27] S. Tessier and D. Otley, A conceptual development of Simons' Levers of Control framework. Management Accounting Research. vol. 23, no. 3 pp. 171-185, 2012.

[28] M. Hall, Realising the richness of psychology theory in contingency-based management accounting research. Management Accounting Research. vol. 31, no. pp. 63-74, 2016.

[29] O.E. Oluwagbemiga, Effectiveness of Regulatory Pronouncements in Curbing Financial Statements Irregularities in Commercial Banks in Kenya. vol., no. 2014.

[30] E.Y. Kasim, Effect Of Government Accountants Competency And Implementation Of Internal Control To The Quality Of Government Financial Reporting. International Journal of Business, Economics and Law. vol. 8, no. 12015a.

[31] H. Xu, et al., Key issues of accounting information quality management: Australian case studies. Industrial Management \& Data Systems. vol. 103, no. 7 pp. 461-470, 2003.

[32]D. Suwanda, Factors Affecting Quality of Local Government Financial Statements to Get Unqualified Opinion (WTP) of Audit Board of the Republic of Indonesia (BPK). Research Journal of Finance and Accounting. vol. 6, no. 4 pp. 139-157, 2015.

[33] M. Nuryanto and N.N. Afiah, The impact of apparatus competence, information technology utilization and internal control on financial statement quality (study on local government of Jakarta province-Indonesia). World Review of Business Research. vol. 3, no. 4 pp. 157-171, 2013.

[34]H. Setiyawati, The effect of Internal Accountants' Competence, Managers' Commitment to Organizations and the Implementation of the Internal Control System on the Quality of Financial Reporting. International Journal of Business and Management Invention. vol. 2, no. 11.19272013.

[35] T.H. Thien, The factors affecting the organization of accounting information systems at public universities in Vietnam. 2017, University of Economics Ho Chi Minh City. 


\section{MEASURING THE IMPACT OF FACTORS ON THE IMPLEMENTATION OF FINANCIAL STATEMENTS UNDER THE NEW ACCOUTING REGIME AT THE PUBLIC SERVICE AND ADMINISTRATION UNITS IN VIETNAM}

[36]T.T.N. Le, Application of IPSAS Standards to the Vietnamese Government Accounting and Financial Statements. 2012.

[37] J.L. Chan, IPSAS and government accounting reform in developing countries. Accounting reform in the public sector: Mimicry, fad or necessity. vol., no. pp. 31-42, 2006.

[38] T. Mardinan, M. Dahlan, and F.K. Fitriyah, Effect of Human Resources, Leadership Style, The Use of Information Technology and Internal Control on the Quality of Financial Statements (Study at Directorate General of Construction, Ministry of Works and Public Housing). Journal of Accounting Auditing and Business. vol. 1, no. 1 pp. 47-61, 2018.

[39] N.J. Ashill, J. Carruthers, and J. Krisjanous, The effect of management commitment to service quality on frontline employees' affective and performance outcomes: An empirical investigation of the New Zealand public healthcare sector. International Journal of Nonprofit and Voluntary Sector Marketing. vol. 11, no. 4 pp. 271-287, 2006.

[40]M. Syaifullah, Influence organizational commitment on the quality of accounting information system. International Journal of Scientific \& Technology Research. vol. 3, no. 9 pp. 299-305, 2014.

[41]C.M. Radaelli and A.C. Meuwese, Better regulation in Europe: between public management and regulatory reform. Public Administration. vol. 87, no. 3 pp. 639-654, 2009.

[42] T.N. Assembly, Law No. 88/2015/QH13 on accounting, T.N. Assembly, Editor. 2015: Hanoi.

[43] S. Korutaro Nkundabanyanga, et al., The association between accounting standards, legal framework and the quality of financial reporting by a government ministry in Uganda. Journal of Accounting in Emerging Economies. vol. 3, no. 1 pp. 65-81, 2013.

[44] H.A. Ouda, Accrual accounting in the government sector. Public Fund Digest. vol. 52, no. 2003.

[45]T.T.C. Thanh and T.T. Yen. The Impact of Accounting Staff Capacity, Applied Accounting Basis and Implementation of Internal Control on Financial Statement Quality: The Case of Public Sector in Binh Dinh Province - Vietnam. in The 24th Eurasia Business and Economics Society (EBES) Conference - Bangkok. 2018b. Thailand: Ebes.

[46] J. van Helden and H. Ouda, Public sector accounting in emerging economies. Critical Perspectives on Accounting. vol., no. 40 pp. 1-7, 2016.

[47] O.S. Ajao, O. Evans, and D. Samuel, Public sector accounting and developing economies: A comparative review and analysis of Ghana and Nigeria. Unique Journal of Business Management Research. vol. 1, no. 3 pp. 034-041, 2013.

[48] T.T. Yen and H.T. Thuy, Factors affecting the quality of financial statements at public education units in Binh Dinh. Accounting and Auditing review vol., no. 172 pp. 55-59, 2018.

[49]R.H. Cheng, An empirical analysis of theories on factors influencing state government accounting disclosure. Journal of Accounting and Public Policy. vol. 11, no. 1 pp. 1-42, 1992.

[50] M. Agung and S. Winarningsih, Effect Of Auditor And Internal Control Competence Apparatus For Local Government Quality Of Financial Reporting. European Journal of Accounting, Auditing and Finance Research. vol. 4, no. 7 pp. 113-127, 2016. 
[51]L.E. Johnson, et al., Management letter comments: Their determinants and their association with financial reporting quality in local government. Journal of Accounting and Public Policy. vol. 31, no. 6 pp. 575-592, 2012.

[52] J. Hair, et al., Exploratory factor analysis. Multivariate data analysis, 7th Pearson new international ed. Harlow: Pearson. vol., no. 2014.

[53] M.o. Finance, Circular No. 107/2017/TT-BTC guiding the administrative and non-business accounting regime V. Ministry of Finance Editor. 2017: Hanoi.

[54]D. Indriasih and P.S. Koeswayo, The Effect of Government Apparatus Competence and the Effectiveness of Government Internal Control toward the Quality of Financial Reporting and its Impact on the Performance Accountability in Local Government. Research Journal of Finance and Accounting. vol. 5, no. 20 pp. 38-47, 2014.

[55]G. Grossi, New development: Consolidated financial reporting as a stimulus for change in Italian local government. vol., no. 2009.

[56] A. Bergmann and D. Bietenhader. Practises and opinions on consolidated financial reporting in Swiss cities. in Workshop on Whole of Government Financial Reporting: International Trends, The University of Siena, Italy. 2008.

[57]J.S. Hulland, The effects of country-of-brand and brand name on product evaluation and consideration: A cross-country comparison. Journal of International Consumer Marketing. vol. 11, no. 1 pp. 23-40, 1999.

[58]J.F. Hair, et al., Mirror, mirror on the wall: A comparative evaluation of composite-based structural equation modeling methods. Journal of the Academy of Marketing Science. vol. 45, no. 5 pp. 616-632, 2017.

[59] J. F. Hair Jr, et al., Partial least squares structural equation modeling (PLS-SEM) An emerging tool in business research. European Business Review. vol. 26, no. 2 pp. 106-121, 2014.

[60]C. Fornell and D.F. Larcker, Structural equation models with unobservable variables and measurement error: Algebra and statistics. Journal of marketing research. vol., no. pp. 382-388, 1981.

[61]A. O'cass and L.V. Ngo, Balancing external adaptation and internal effectiveness: Achieving better brand performance. Journal of Business Research . vol. 60, no. 1 pp. 11-20, 2007.

[62]B. Tabachnick, L. Fidell, and S. Osterlind, Using mulfivariate stafisfics. Needham Heights, MA: Allyn g Bacon. vol., no. 2001.

[63] J. Henseler, C.M. Ringle, and M. Sarstedt, A new criterion for assessing discriminant validity in variancebased structural equation modeling. Journal of the academy of marketing science. vol. 43, no. 1 pp. 115-135, 2015.

[64]J. Henseler, G. Hubona, and P.A. Ray, Using PLS path modeling in new technology research: updated guidelines. Industrial management \& data systems. vol. 116, no. 1 pp. 2-20, 2016.

Received on February 1st, 2019

Accepted on March 25th, 2019

(C) 2019 Industrial University of Ho Chi Minh City 